\title{
TFE3 Gene Translocation
}

National Cancer Institute

\section{Source}

National Cancer Institute. TFE3 Gene Translocation. NCI Thesaurus. Code C153272.

A cytogenetic abnormality that refers to a translocation involving the TFE3 gene. 